


\title{
Citizens 'participation in the fight against criminal offences: political and legal aspects
}

\author{
DOI: https://doi.org/10.46398/cuestpol.3969.12
}

\author{
Yevhen Leheza * \\ Yuliia Dorokhina ** \\ Oleksandr Shamara *** \\ Serhii Miroshnychenko **** \\ Vita Moroz ${ }^{* * * * *}$
}

\section{Abstract}

The aim of the research is to reveal political and legal aspects at international level in the field of citizens' participation in the fight against crime. Attention is paid to the most common forms of public participation: patrolling; provide information on criminals or criminal acts committed; participation in anti-corruption measures; assistance in the resocialization of offenders; aiding victims of crime; strengthening the security of one's own property; participation in information on anti-criminal measures. Methodologically it is a documentary research. In conclusion, the benefits of public participation in crime prevention, based on international crime prevention, can be divided into two groups: basic and additional. The main advantages are reduction of crime and delinquency; improve security in relevant areas of cities; reducing citizens' fear of crime; strengthening the service function of the police forces in relation to the inhabitants of territorial communities; improve police partnerships with the public.

* Yevhen Leheza, Professor, Doctor of Science in law, Professor at the Department of Administrative and Customs Law, University of Customs and Finance, Ukraine. ORCID ID: https://orcid.org/oooo-ooo19134-8499. Email: yevhenleheza@gmail.com

** Yuliia Dorokhina, Doctor of Law, Professor, Professor of the Administrative Law and Administrative Process Department of Institute of Law of Taras Shevchenko National University of Kyiv, 64/13, Volodymyrska Street, City of Kyiv, Ukraine, 01601, ORCID ID : https://orcid.org/oooo-0002-27993933. Email: zdobuvach@ukr.net

*** Oleksandr Shamara, PhD in Law, senior scientific officer, Professor of the Department of Law, Dniprovsky Humanitarian University Dnipro, Ukraine. ORCID ID: https://orcid.org/oooo-00020571-0437. Email: alexandr79shamara@gmail.com

**** Serhii Miroshnychenko Doctor of Law, Associate Professor, Professor of the Department of Criminal Law and Criminology, University of the State Fiscal Service of Ukraine, Irpin, Ukraine. ORCID ID: https://orcid.org/oooo-0003-4792-6081. Email: Miroshnychenko@email.ua

***** Vita Moroz, PhD in Law, Associate Professor Associate Professor administrative law, process and administrative activities, Dnipropetrovsk state University of Internal Affairs, Dnipro, Ukraine. ORCID ID: https://orcid.org/oooo-ooo3-4433-3731. Email: 0675631677@ukr.net 
Keywords: crime prevention; citizen participation; international experience; forms of public participation in crime prevention; Ukraine.

\section{Participación de los ciudadanos en la lucha contra los delitos penales: aspectos políticos y legales}

\section{Resumen}

El objetivo de la investigación es revelar aspectos políticos y legales en el plano internacional en el campo de la participación de los ciudadanos en la lucha contra el delito. Se presta atención a las formas más comunes de participación pública: patrullaje; proporcionar información sobre criminales o hechos de delitos cometidos; participación en medidas anticorrupción; asistencia en la resocialización de delincuentes; brindar asistencia a las víctimas de delitos; fortalecer la seguridad de la propiedad propia; participación en la información sobre medidas anticriminales. Metodológicamente se trata de una investigación documental. A modo de conclusión, en cuanto a los beneficios de la participación pública en la prevención del delito, basada en la práctica internacional en este ámbito, se pueden dividir en dos grupos: básicos y adicionales. Las principales ventajas son: reducción del crimen y la delincuencia; mejorar la seguridad en áreas relevantes de las ciudades; reducir el miedo de los ciudadanos a la delincuencia; fortalecer la función de servicio de los cuerpos policiales en relación con los habitantes de las comunidades territoriales; mejorar las asociaciones de la policía con el público.

Palabras clave: prevención del delito; participación ciudadana; experiencia internacional; formas de participación pública en la prevención del delito; Ucrania.

\section{Introduction}

The purpose of most criminological research is to develop promising areas of crime prevention. The implementation of this scientific task is impossible without a study of foreign crime prevention practices, given the assessment of its effectiveness for possible implementation in Ukraine and even critical evaluation. Thus, the foreign practice of crime prevention with the participation of one of the many actors in this activity, which is the public, is of scientific interest. 
Yevhen Leheza, Yuliia Dorokhina, Oleksandr Shamara, Serhii Miroshnychenko y Vita Moroz Citizens 'participation in the fight against criminal offences: political and legal aspects

The literature rightly points out that the most important part of the content of comparative law research is knowledge that has a functional nature, goes beyond national legal systems and is a universal theoretical and practical value (Bekhruz, 2003). This can be supplemented by the words of O. Yu. Shostko, who emphasized that taking into account the experience of other countries is always an additional positive factor that allows a more rational approach to the development of their own safety models (Shostko, 2012). Similar ideas of scientists are reflected in the regulations of law enforcement agencies, which define new approaches to crime prevention in Ukraine. In particular, the Development Strategy of the System of the Ministry of Internal Affairs of Ukraine for the period up to 2020, approved by the Cabinet of Ministers of Ukraine dated November 15, 2017 № 1023-r, emphasizes that the Strategy will be implemented taking into account the positive experience and best practices of leading countries (Development Strategy of the System of the Ministry of Internal Affairs of Ukraine for the period up to 2020, 2017).

In this regard, we believe that the study of other countries' practice on public use in crime prevention deserves attention and is justified from the standpoint of criminology for a number of reasons: a) the prevalence of comparative law research corresponds to a trend of modern criminology (Kolodiazhnyi, 2017); b) focus on the implementation of regulations that define modern approaches to crime prevention in Ukraine; c) consistency with the European integration vector of Ukraine's development, including in the law enforcement sphere; d) is the basis for the possible expansion of certain areas of public participation in crime prevention in our country.

\section{Literature review}

V. V. Holina, O. Dzhafarova,V. M. Dromin, M. H. Kolodiazhnyi, Ye. Leheza, Yu. Shostko, M. Savielieva, S. A. Zadorozhnyi and others paid attention to the study of foreign experience in crime prevention, including with the participation of the public. In the works of some scientists, the issue under consideration was highlighted through the presentation of opinions on the prevention of certain crimes. Others studied public involvement in law enforcement separately by country.

This form of public participation in crime prevention is the most common abroad. According to some scholars, patrolling can be attributed to a historically rooted type of law enforcement, which has subsequently improved, changed its forms and means of achieving the main goal of law enforcement (Kolodiazhnyi, 2018). In our opinion, such an improvement can be attributed to the expansion of police patrols, which include citizens. In general, patrolling is characteristic not only of the developed western 
countries of the world, but also of less socially prosperous Latin American, African and Asian countries.

The main trends in preventing and combating corruption in democracies are, first, a clear correlation and relationship between the level of democratization of society and corruption (the more in a democracy, the less corruption there); secondly, civil society is seen as the main subject of influence on the government - and, accordingly, as the primary subject of anti-corruption (Zadorozhnyi, 2017).

\section{Results and discussion}

The central methodological component of criminological knowledge of modern foreign experience of public participation in crime prevention is the consideration of forms of such activities. Various foreign forms of public participation in crime prevention can be divided by their nature into the following: a) patrolling; b) providing information about criminals or facts of committed crimes; c) participation in anti-corruption measures; d) assistance in resocialization of offenders; e) providing assistance to victims of crime; f) strengthening the security of own property; g) participation in information anti-criminogenic measures; g) other forms.

Patrol. The practice of public patrol in the United States is quite powerful given the quantitative composition and variety of activities. This is facilitated by the presence of special organizations (volunteer councils, public commissions at municipalities), which deal with the issues of diversification of police patrols, increasing its effectiveness, funding. The most well-known public patrol organization in the United States and around the world is the Guardian Angels, which since 1979 have helped police maintain law and order not only in the United States but in many other parts of the world. Guardian Angels is a voluntary non-governmental organization that patrols subway stations, streets and other public places on a gratuitous basis (Leheza et al., 2018). In general, different (both combined patrols and patrols consisting exclusively of civilians) operate in all US states. According to the US Department of Justice's Community Oriented Policing Services, the most effective crime prevention programs in the country to engage Americans in patrols are: "Volunteers to Help the Police" (Phoenix, Arizona); "Neighborhood Patrols" (Millersville, Maryland); "Street patrols counter thefts and carjacking" (Ardmore, Pennsylvania), etc.

The intensification of public patrols in Great Britain was facilitated by the adoption in the early 1990 os of special programs, one of which was Street Patrol (Vedernykova, 2001), as well as the creation of a public patrol service (Community Support Officers) and special constables. The members of this organization protect public order as part of mixed patrols and have no right 
to use force against offenders. Their main task is to reveal the facts of the committed crimes and to report various incidents by walkie-talkie. The efficiency of their activities is quite high, which is ensured by strengthening social control in public places.

The practice of public patrolling in China is quite widespread and widespread. In Beijing alone, up to 850,000 volunteers are involved in maintaining public order. The peculiarity of Chinese patrols is the age of the patrols, as most patrols are people of retirement age from 50 to 70 years. They help the police to detain criminals and report the facts of crimes and offenses on a gratuitous basis. Such patrols are intensifying in China on the eve of Chinese New Year, other national holidays and mass cultural and entertainment events (Connor, 2018).

Providing information about criminals or the facts of crimes committed. One of the world's best-known crime prevention programs, designed to encourage citizens to provide any anonymous information about crimes or criminals, is the Crime Stoppers program. This project was first introduced in the United States in 1976. As of 2018, the international platform "Crime Stoppers" involves 26 countries, including the United States, Britain, Canada, the Netherlands, Australia, South Africa, New Zealand, and other Latin American and African states. Sources of funding for anonymous information about criminal events are sponsorship of legal entities, donations from citizens, gifts, inheritance, etc. Since 2010, the project has maintained a strategic partnership with the International Criminal Police Organization (Interpol), and since 2016 - with the United Nations Office on Drugs and Crime (UNODC) (Leheza et al., 2018).

In some countries, in addition to the Crime Stoppers project, there are other additional prevention programs aimed at activating the public to provide information about the crimes committed, especially high-profile crimes. These include the United States, which has strong funding for this activity, as well as broad support for such initiatives by civil society. In particular, in Stafford, New Jersey, a program "Crime Alert". It is to persuade Americans to participate in the program. All persons who wish to report crimes and offenses anonymously, in order to secure them and enhance the anonymity of messages, are issued special identification numbers (QR-codes), which exclude the leakage of any information about the perpetrator.

It will be recalled that in Ukraine, in contrast to many Western countries, the practice of monetary and other incentives for conscious citizens who provide information about crimes and criminals is not widespread. There is no appropriate legal framework that would legally determine the conditions of anonymous reporting of the facts of crimes committed. The only exception is the Law of Ukraine "On Prevention of Corruption" of 2014, where in Art. 53 defines the conditions of state protection of persons who 
provide assistance in preventing and combating corruption. At the same time, there is no norm on encouraging whistleblowers.

Participation in anti-corruption measures. Non-governmental organizations have a strong opportunity in this area, the main task of which is to expose corruption. Researchers of public involvement in the prevention of corruption crimes in foreign countries have identified a number of non-governmental organizations with international status. These are: Transparency International, International Anticorruption Resource Center, Corruption Watch, Transparify and others (Biletskyi, 2018). The analysis of the activities of these and other non-governmental organizations allowed us to conclude that their anti-corruption influence is embodied through the following measures: formation and implementation of anti-corruption policy; evaluation of anti-corruption mechanisms used by governments; collection and processing of information on corruption cases; detection of corruption risks; providing legal assistance; development and implementation of educational programs; formation of anti-corruption worldview of citizens.

Sweden is one of the countries least affected by corruption. In this country, there is effective public control over the activities of both the public and private sectors, the leading role in which is played by the media, the church and public opinion. However, the latter may create a negative image of businessmen or officials, as a result of which some will be forced to resign, while others will lose trust among business partners.

Similarly, public control over the activities of government agencies, as well as the cultivation of intolerance in society to any manifestations of corruption takes place in Switzerland, the Netherlands, the United States, France, Poland and others.

As for the United States, in this country the institution of public anticorruption oversight is provided by the Freedom of Information Act of 1966, according to which all federal agencies must provide citizens with free access to all available declassified information. Thanks to this law, it has become more possible to expose corruption. Such activities are carried out by a number of non-governmental organizations in the United States: Judicial Watch, Project on Government Oversight, Government Accountability Project, and others.

For example, in Seoul in 1999, the anti-corruption program "OPEN" was developed, which allowed citizens to control the work of officials. This allows you to monitor at any time the process of reviewing documents for applications for permits in a particular case, especially when there is the highest likelihood of corruption.

Canada does not have special anti-corruption agencies, and its anticorruption system is built on active public participation through the media, professional associations and organizations. 
As you can see, the role of the public in preventing corruption in foreign countries is quite important, and most importantly has a practical focus, which is:

- supervision, ie the public closely monitors legislative and institutional changes, transparency in the formation and functioning of government, as well as corruption cases (from disclosure to investigation, prosecution and trial).

- developing viable experience and knowledge of viable alternatives through the development of bills, concepts of institutional reforms and educational campaigns.

- influence as one of the most important tools that can be used to exert public pressure on government and officials in making specific decisions.

- actions, namely the provision of services in the social sphere, the publication of information on cases of corruption and raising awareness of a wide range of citizens.

Assistance in resocialization of offenders. This form of public participation in crime prevention is especially common in the developed western countries of the world, which are characterized by a relatively humane criminal policy. It is characterized by a low percentage of convictions related to imprisonment, as well as the widespread use of the practice of release from probation (Dromin, 2007). Therefore, resocialization can be both penitentiary and post-penitentiary in nature.

For example, in France and the United Kingdom, public resocialization penitentiary practice is that a number of social, educational and other activities are carried out by representatives of non-governmental, public structures, and semi-state entities. Such measures include: development of specific social programs, their implementation, provision of social assistance, involvement in social work of the necessary specialists on a voluntary basis and assistance to convicts. In Finland, there is an Association for Probation and Further Supervision to help solve the social problems of parolees and released prisoners, which also includes some nongovernmental organizations. A feature of penitentiary resocialization in Germany is the wide participation of the church and religious organizations (Barash, 2016).

Post-penitentiary resocialization is characterized by the fact that convicts who are at large after committing a crime are obliged to participate in mediation programs, probation, the practice of reconciliation with the victim, attend special rehabilitation psychological, pedagogical, and medical and social courses and trainings on taming aggression, treatment of alcoholism and drug addiction, changes in life attitudes and values, etc. 
The main thing is that the public (parents of criminals, social workers, priests, socially active youth, volunteers, etc.) takes an active part in such a practice of assisting in the resocialization of criminals and offenders.

Often post-penitentiary resocialization of offenders in foreign countries is carried out within the framework of special prevention programs. Consider some of them. Thus, the "Volunteers to Help the Police" program in Phoenix, Arizona, USA, proved to be quite effective. Its purpose is to involve interested and qualified citizens-volunteers in the performance of certain functions of law enforcement agencies. In particular, the city police department involved more than 3,000 volunteers who had no criminal record, were specially checked by the police to carry out a number of resocialization measures with criminals and persons released from prisons (lectures, legal aid, psychological training, employment assistance).

In Belfast, the capital of Northern Ireland, a successful program called The RIO project (RIP) was launched in 2009 and is still ongoing. The aim of the program is the post-penitentiary resocialization of persons aged 17 to 21 who have been released from prisons or who have problems with the law. Under the program, a special police officer is the operator between young people who have received resocialization services and the providers of these services, who are often NGOs, volunteers and other interested NGOs. The latter provide legal, psychological, social, and other assistance to young people to prevent their recidivism (Williams, 2014).

Assistance to victims of crime is also considered a common area of public involvement in crime prevention in many countries around the world. The pioneers in this area are the most democratic and socially prosperous countries (USA, Central Europe), where the protection of the rights of victims of crime is given much attention. In many EU member states, special information booklets are developed and distributed by volunteers and representatives of human rights NGOs among victims of crime. They explain the rights of victims of crime and the algorithm for further action to restore the violated rights as a result of the crime (Victims Support Program, 2013). Many foreign countries also have both national and local assistance programs for victims of crime.

For example, in Fort Lauderdale (Florida, USA) a program was provided to provide a free lawyer for victims of crime. The local police department received a grant to raise funds for the training of highly qualified legal staff to defend the interests of poor victims of crime in court. A similar program is also being implemented in Aurora (Colorado, USA). 35 women volunteers have been invited to provide free assistance to victims of crime around the clock. These women go to crime scenes, provide psychological counseling, and provide psychological support to victims for several weeks after the crime. 
European countries are also actively developing ways to support victims of crime. In many countries, such as Spain, special emphasis is placed on the protection of victims of domestic violence, as this problem is acute for the European community. To this end, in many cities in the province of Spain, for example, in Catalonia (Barcelona, Girona, Lerida, Tarragona), in 2011 the project "Program of security and support for victims of gender and domestic violence" was launched. This program is also designed for children and the elderly. Its separate block includes measures to involve individual citizens and NGOs in providing various types of assistance to victims of crime and delinquency (Williams, 2019).

Strengthening the security of own property. This form of public participation in crime prevention in foreign countries is associated with well-known in the criminological literature measures to prevent protection (Holina, 2011). It consists in the fact that citizens, on the recommendation of the police or on their own initiative, take various measures aimed at strengthening the technical security of their own property (apartment, private house, car, shop, utility room). As a result, such public activity contributes to the strengthening of technical security of property, which complicates and even prevents the implementation of certain criminal encroachments on theft, destruction, damage to property, car theft, hooliganism, robbery or burglary, including combined with burglary, etc.

In many foreign countries (USA, Great Britain, Germany, Canada, Australia) in police departments there is a position of the police officer responsible for carrying out check of protection of property of citizens. After the relevant inspection, the property owner is given advice by the employee to strengthen the technical protection: strengthening the door frame; installation of additional locking devices; installation of the alarm system; improving the lighting of the adjacent territory; additional glazing of windows; storage of cash and valuables only in a secure safe, etc. Similar advice is given, for example, by the London police to the population of this city. After taking the necessary technical measures at their own expense, the police provide citizens with special stickers that are pasted on the windows and all doors of the house and signal the participation of the property owner in the home security audit program (Thirteenth united nations congress on crime prevention and criminal justice, 2015).

Similar prevention programs called "Business Security Audit" exist in many Western countries for entrepreneurs and legal entities in the field of trade and services. In particular, business representatives are provided with advice on the procedure for technical arrangement of trade halls, utility rooms (installation of alarm buttons and video surveillance cameras), rules for placing goods on shelves and shop windows in order not to violate visibility, etc. (Official web-site of the gov.uk, 2020). 
Participation in information anti-criminogenic activities. In many foreign countries, including Latin and North America, Europe, Africa, and Asia, the appropriate level of involvement of non-state actors in crime prevention is achieved through appropriate information campaigns. They provide a solid socio-psychological basis for activating civil society in the field of crime prevention and increasing the social responsibility of citizens for the results in this area.

In the United States, it is common practice to declare the so-called days without crime, when the march of the participants of such an action is carried out, citizens are given newsletters with advice to reduce victimization from various crimes. In some cities in the United States and Great Britain, residents of certain residential areas are involved in creating profiles of residential areas by the police to clarify possible patrol routes with the help of the population, people who lead a criminal lifestyle, use drugs, and others. In the Canadian province of Saskatchewan, the practice of establishing so-called social services departments has proved its worth. They also include volunteers and members of public organizations, who, moving in a special car equipped with a walkie-talkie, urgently go to the scene (crime, fire, accident, catastrophe), where they provide information and counseling to victims.

In African countries (Botswana, Zimbabwe, Lesotho, Nigeria, Kenya, Malawi, Uganda, Sierra Leone), the experience of providing free legal aid by lawyers on a voluntary basis to both criminals and victims of crime has recently become widespread (Holina and Kolodiazhnyi, 2015).

Other forms of public participation in crime prevention in foreign countries include: the involvement of residents of neighborhoods in the arrangement of living space within the theory of "broken windows" (USA, UK, Netherlands). As a result, the social responsibility of citizens increases, criminogenic conditions for committing many selfish and violent crimes by cutting down bushes and dry trees, dismantling dilapidated buildings that serve as shelters for drug addicts, etc .; Involvement of women-volunteers from neighborhood clubs and community groups to perform non-police registration functions in police departments (receiving applications and complaints from visitors; advising on non-legal issues) (New York, NY, USA); involvement of male volunteers in secondary unskilled policing (traffic regulation, response to reports of antisocial behavior) (Dayton, Ohio, USA), etc.

\section{Conclusion}

1. Thus, regarding the benefits of publicinvolvement in crime prevention, based on foreign practice in this area, they can be divided into two 
groups: basic and additional. The main advantages are reduction of crime and delinquency; improving security in relevant areas of cities; reducing citizens' fear of crime; strengthening the service function of police bodies in relation to residents of territorial communities; improving police partnerships with the public. Additional advantages of such activities are deepening the democratization of society; changing the psychology of local residents in the direction of strengthening the sense of unity, tolerance, courtesy and social responsibility; increasing citizens' trust in the police. By the way, according to the latest indicator, according to the Law of Ukraine "On the National Police" of 2015, it is proposed to assess the degree of efficiency of the police in our country.

2. Consideration of modern foreign practice of public participation in crime prevention provides grounds for possible borrowing of its individual components in order to improve the activities of law enforcement agencies of Ukraine, as well as the formation of the latest strategy to combat crime.

\section{Bibliographic References}

BARASH, Yevhen Yukhimovich. 2016. "Foreign experience of social work with convicts" In: Scientific Bulletin of the Institute of Criminal-Executive Service. Vol. 1, pp. 10-17.

BEKHRUZ, Hashmatullah. 2013. "Comparative jurisprudence: modern aspects of research" Comparative jurisprudence. Vol. 1-2, pp. 278-285.

BILETSKYI, Andrey Vladimirovich. 2018. Public participation in the prevention of corruption in Ukraine: Thesis for the PhD in Law. Kharkiv, Ukraine.

CONNOR, Neil. 2018. China deploys of elderly volunteers to keep the peace after Beijing knife rampage. The telegraph. Available online. In: https:// https://www.telegraph.co.uk/news/2018/02/12/china-deploys-armyelderly-volunteers-keep-peace-beijing-knife/. Consultation date: 11/11/2020.

DROMIN, Victor Nikolaevich. 2007. "The evolution of punishment in the context of preventive opportunities: from imprisonment to probation" In: Current issues of state and law: collection of research papers. Legal lit. Vol. 32, pp. 265-271.

HOLINA, Vladimir Vasilyevich. 2011. Crime prevention (theory and practice). Study guide. National Law Academy of Ukraine. Kharkiv, Ukraine. 
HOLINA, Vladimir Vasilyevich; KOLODIAZHNYI, Maxim Gennadyevich. 2015. "World crime: current trends and countermeasures" In: Bulletin of the National Academy of Legal Sciences. Vol.2, pp. 92-100.

KOLODIAZHNYI, Maxim Gennadyevich. 2017. Modern foreign experience of public influence on crime. Monograph. Law. Kharkiv, Ukraine.

KOLODIAZHNYI, Maxim Gennadyevich. 2018. "Patrolling as a component of a strategy to reduce the possibility of committing crimes" In: Bulletin of the Criminological Association of Ukraine: collection of research papers. KhNUVS. Vol. 1, pp. 37-46.

LAW OF UKRAINE. 2017. Development Strategy of the System of the Ministry of Internal Affairs of Ukraine for the period up to 2020, approved by the Cabinet of Ministers of Ukraine. № 1023-r. Available online. In: https:// zakon.rada.gov.ua/laws/show/1023-2017-\%D1\%80\#Text. Consultation date: $11 / 11 / 2020$.

LEHEZA, Yevhen; SAVIELIEVA, Maryna; DZHAFAROVA, Olena. 2018. "Structural and legal analysis of scientific activity regulation in developed countries". Baltic Journal of Economic Studies. Vol. 4 (3), pp. 147-157. Available online In: https://doi.org/10.30525/2256-0742/2018-4-3147-157. Consultation date: 11/11/2020.

OFFICIAL WEB-SITE OF THE GOV.UK. 2020. Police community support officers (pcsos) and special constables. Available online In://www.gov. $\mathrm{uk} /$ police-community-support-officers-what-they-are. Consultation date: 11/11/2020.

SHOSTKO, Elena Yuriyivna. 2012. Theories of the causes of juvenile delinquency in modern American criminology: scientific-practical manual. Ed. magazine. Law of Ukraine. Kyiv, Ukraine.

THIRTEENTH UNITED NATIONS CONGRESS ON CRIME PREVENTION AND CRIMINAL JUSTICE. 2015. National approaches to public participation in strengthening crime prevention and criminal justice. Working paper. Available online. In: https://www.unodc.org/ documents/congress/Documentation/Report/ACONF222_17e_ V1502929.pdf. Consultation date: 11/11/2020.

VEDERNYKOVA, Olga Nikolaevna. 2001. Theory and practice of combating crime in Britain. Moscow, Russia.

VICTIMS SUPPORT PROGRAM. 2013. Available online In: https://www. legislation.nsw.gov.au/view/whole/html/inforce/current/act-2013037. Consultation date: 11/11/2020. 
Yevhen Leheza, Yuliia Dorokhina, Oleksandr Shamara, Serhii Miroshnychenko y Vita Moroz

WILLIAMS, Naomi. 2014. "100 Promising Practices on Safer Cities: Collation of Urban Safety Practices. The International Centre for the Prevention of Crime; The European Forum for Urban Security". United Nations Human Settlements Programme. Available online. https://slidelegend. com/100-promising-practices-on-safer-cities_59b49e191723dd6c734 1f362.html. Consultation date: 11/11/2020.

ZADOROZHNYI, Sergey Anatolyevich. 2017. Mechanisms for preventing and combating corruption in local authorities. Thesis for the PhD in Law. Ivano-Frankivsk, Ukraine. 
Vol. 39 N $^{\circ} 69$

Esta revista fue editada en formato digital y publicada en julio de 2021, por el Fondo Editorial Serbiluz, Universidad del Zulia. Maracaibo-Venezuela 